\title{
Assessment of Occupational Health and Safety among Scavengers in Gaza Strip, Palestine
}

\author{
Issam A. Al-Khatib $\mathbb{D D}^{1}{ }^{1}$ Majed I. Al-Sari', ${ }^{2}$ and Stamatia Kontogianni ${ }^{3}$ \\ ${ }^{1}$ Institute of Environmental and Water Studies, Birzeit University, Birzeit, State of Palestine \\ ${ }^{2}$ Universal Institute for Applied and Health Research (UIAHR), \\ The Joint Service Council for Solid Waste Management for Hebron and Bethlehem Governorates (JSC-H\&B), Bethlehem, State \\ of Palestine \\ ${ }^{3}$ Laboratory of Heat Transfer and Environmental Engineering, Dpt. of Mechanical Engineering, \\ Aristotle University of Thessaloniki, Thessaloniki, Greece
}

Correspondence should be addressed to Issam A. Al-Khatib; ikhatib@birzeit.edu

Received 4 October 2019; Accepted 3 January 2020; Published 24 February 2020

Academic Editor: Jonathan Haughton

Copyright (c) 2020 Issam A. Al-Khatib et al. This is an open access article distributed under the Creative Commons Attribution License, which permits unrestricted use, distribution, and reproduction in any medium, provided the original work is properly cited.

\begin{abstract}
This study deals with the occupational health and safety of valuable and recyclable waste collectors (called scavengers) in the Gaza Strip, Palestine. The analytical descriptive approach was used in this study to achieve this goal. Waste pickers in the study area are working informally at existing dumpsites, solid waste transfer stations, landfills, and community streets' bins areas. A sample of 301 scavengers was surveyed filling a structured questionnaire designed for this purpose, during individual interviews. In addition, interviews with key Palestinian officials in the Gaza Strip have been conducted to provide accurate data and comprehensive information regarding waste pickers activities. The results showed that the occupational health and safety of the waste pickers is in constant deterioration mainly due to the informal nature of their work. The waste pickers are reportedly suffering in the current situation and the majority has no access to potable water, sanitation, and hygienically appropriate place to sleep and have meals. None of them has ever received occupational health and safety training. The study recommends that local decision makers should uptake short-term and long-term measures in waste management sector both aiming at improving this vulnerable social group's health and safety life status.
\end{abstract}

\section{Introduction}

In most cities of the developing countries, thousands of people are depending on the collection of recyclable materials for their livelihoods [1], and it is reported that up to $2 \%$ of the population in Asian and Latin American cities lives on scavenging income [2]. Gaza Strip is the largest area under siege in the world. Blockade and restrictions on movement imposed by the Israeli occupation cause deterioration in the local economic conditions. Most of residents are refugees living in deep poverty and unhealthy conditions. The World Bank has reported that the economy is in "free fall" and half the population is living under the poverty line [3]. Mobility restrictions have directly affected the available possibilities for men and women to access health, education, and income, as well as sustain family and other social networks. The economic crisis in the Gaza Strip and lack of access to livelihood has forced several people to work as waste pickers, collecting recyclable materials from the generated municipal solid waste and selling them to manufacturers in order to generate income $[4,5]$. The phenomenon of the waste pickers is spread across Palestine in the Gaza Strip as well as in the West Bank. Most of the waste pickers in Palestine are working informally at random dumps. The Wadi Al-Shaer Joint Service Council for Solid Waste Management (WSJSC-SWM) reported the presence of 4 waste pickers at Anabta dumpsite [6]. The Joint Service Council for Solid Waste Management (JSC-H\&B) reported the presence of 81 waste pickers were working at Yatta dumpsite, which is located at the southern part of the West 
Bank, before the closure of the site [7]. Eco Con Serv and Universal Group-Gaza reported the presence of 11 waste pickers at Khan Younis solid waste transfer station and 18 waste pickers at El-Fukhary landfill [8].

In accordance with the interviews held with Joint Service Council for Gaza and North Gaza Governorates, Municipal Development and Lending Fund (MDLF), and the Environmental Quality Authority (EQA), the waste pickers in the Gaza Strip belong into three categories, based on their "job" area:

(i) Recyclables collection from the bins distributed along the streets in the community

(ii) Informal sorting at the solid waste transfer stations

(iii) Recyclables collection at the dumpsites and landfills

All waste pickers are working informally and independently as they not belonging to any company or organization related to integrated solid waste management. Law prohibits informal work at solid waste management facilities; however, the local authorities in the Gaza Strip are not able to prevent the waste pickers' activity due to sympathy and concerns on their financial status. Despite their occupational unhygienic environment, regulation, monitoring, or even enforcement to regulate their work is not available [9].

Waste pickers belong to poor and marginalized social groups and are often vulnerable to a variety of occupational health risks and diseases [10-13]. They represent the informal grassroots of the local solid waste recycling system, yet they are not taken into consideration by any waste management policy [14-17].

Overall, workers in the solid waste sector including informal waste pickers are vulnerable to three major health risks: accidents, infection, and chronic diseases. Accidents could lead to injury or death and could be caused by heavy equipment, trucks, holding recyclable materials, fire outbreaks, falling from heights when dumping face is high, and buried in the waste. Infections is caused by direct contact with waste and infected wound, infected dust, bites from wild animals, and enteric infections transmitted by insects feeding on waste. Chronic diseases including chronic respiratory diseases result from exposure to dust and toxic and carcinogenic risks as a result of exposure to hazardous compounds, cardiovascular disorders, and heat stress due to exposure to excessive temperature, and hearing function loss result from exposure to excessive noise. Most of the aforementioned incidents frequently occur in most businesses, when training programmes are not regularly implemented.

To this direction, the profession of scavengers is also marked by many risks $[18,19]$. Previous studies, worldwide, reveal numerous health problems among the waste pickers population [11, 19-26]. Also, previous studies have shown incidences of infectious diseases among waste pickers as a result of exposure to hazardous substances [27], for example, feces, contaminated needles, toxic paper, heavy metals from batteries, bottles, and chemical waste containers.
A study of 48 waste pickers in Santo André, Brazil, showed that almost all workers reported having back, hand, leg, arm, and shoulder pain [28] due to the lifting of heavy objects.

In particular, waste pickers working in open dumps are exposed to large quantities of toxic vapors and other serious threats such as the possibility of being run over by dump trucks to landfill, fire exposure, or falling due to surface decline. They are exposed to nonfatal and sometimes fatal occupational hazards and accidents. However, some studies have showed increased risk of musculoskeletal problems [29] and workrelated respiratory gastrointestinal and skin problems [30]. The exposure to microbes as well as dust during their work is likely to have cumulative effect and health problems to emerge in the long term [31]. Usage of protective equipment (gloves and uniform) may, in large extent, minimize the involved risks. Yet, studies have revealed very low usage rates [21, 22, 32]; hence, the scavengers are vulnerable to injuries by sharp objects (needles, broken glass, metal, and so on) and animals (dog bites, rat bites, and so on) [33].

Municipal cleaners also face similar problems as scavengers based to a study conducted in the Nablus governorate [34]. This has been also crosschecked with the Environmental and Social Impact Assessment outcome of Al-Minya sanitary landfill in the southern West Bank of Palestine [35].

The issues described so far do not constitute common knowledge in Palestine and in the Gaza Strip; therefore, the aim of this study is to identify in the field and communicate the occupational hazards that scavengers are exposed to in the Gaza Strip.

\section{Research Methodology}

The study population consists of all scavengers working in the Gaza Strip. A random sample of the study population was selected in accordance with the Herbert Larkin equation [36], as shown in the following equation.

$$
n=\frac{(1-p)}{(\mathrm{SE} / t)+[p(1-p) / N]},
$$

where $N=$ study population (1200); $n$ : sample size; $t$ : confidence coefficient and equal to 1.96 for $95 \%$ confidence interval; $p$ is the value of the main estimate, which is a relative index assumed to be $50 \%$ in order to give the largest sample size possible for this type of indicator; SE: the standard error ratio is equal to 0.05 . A minimum sample size of 291 is needed. A sample of 301 scavengers was interviewed.

The data were collected via a structured questionnaire designed for the purpose that is to record comprehensive information regarding occupational health and safety of the waste pickers. Questionnaires were provided during personal interviews with the waste pickers. Prior to the research conduction, the questionnaire was tested in pilot-interviews, and appropriate modifications were performed. It included the following sections: general information, awareness and education, occupational health and safety, social aspects, and trade unions. The overall focus was on the workplace environment status, working hours, accidents recording, 
perceptions of occupational hazards, recorded occupational diseases, availability of safety equipment, customized safety procedures, the culture and awareness, availability of health insurance, provided medical services, and other related topics. All participants were informed of the field research aims prior to the interview conduction, to facilitate the data collection process and to obtain their prior consent to data collection.

Another part of the overall study was the communication with relevant decision-makers and specialists of the Palestinian officials related to the research scope, namely, the Joint Service Council for Gaza and North Gaza Governorates, the Municipal Development and Lending Fund (MDLF), and the Environmental Quality Authority (EQA). This communication largely assisted the cross reference of the interviews' collected data and its connection to current situation.

\section{Results and Discussions}

3.1. Socioeconomic Conditions of the Waste Pickers (Scavengers). The study sample was selected to represent all parts of the Gaza Strip. The distribution of the sample was $20.6 \%$ from the north Gaza district, $26.9 \%$ from Gaza district, $10.6 \%$ from Deir Al-Balah area, 33.6\% from Khan Younis, and $8.3 \%$ from Rafah area. The results showed that all of the waste pickers are males. The socioeconomic status of the study sample is shown in Table 1 .

The socioeconomic conditions analysis showed that $50.2 \%$ are aged between $19-30$ years; $52.5 \%$ of them are married; $83.4 \%$ are permanent city residents; and $62.5 \%$ belong to families consisting of 5-10 members. The vast majority of the waste pickers are living in deep poverty; the average monthly income generated from working in the waste recycling is less than NIS 500 for $71.9 \%$ of them (1 $\mathrm{USD}=3.5 \mathrm{NIS}$ ), and the education level of $60.5 \%$ of them is that of preparatory or secondary school. In comparison with other studies, Schenck et al. [37] found that $47 \%$ of the waste pickers are married in Pretoria. In accordance with Figueiredo et al. [38]; $56 \%$ of the waste pickers are aged between $18-34,72 \%$ of them were of primary education level, and $72 \%$ of them are generating income in the range of 300-500 $\mathrm{BRL}(1 \mathrm{BRL}=0.25 \mathrm{USD})$ from working in collection and selling recyclables. Schenck et al. [39] found that the average age of the waste pickers was 39 years. According to Women in Informal Employment, Globalizing and Organizing [40], $43 \%$ of 760 surveyed waste pickers were in the age range of 26-40 years. Moreover, $49 \%$ of the waste pickers were aged in the range of 41-50 years according to Schenck et al. [37]. The United Nations Inter-Agency Task Force on Social and Solidarity Economy reported that International Labor Organization (ILO) has estimated approximately 15-20 million informal waste workers worldwide generating a very low income, often living below the poverty level [41]. In 2012, Schenck et al. conducted a study on waste pickers' population in South Africa and found out that the percentage of men was slightly higher (52\%) than the percentage of women (48\%). Schenck et al. [39] found that $60 \%$ of the waste pickers were men and $40 \%$ were women.
The working hours for most of the waste pickers range between five and twelve hours per day; five to eight for $55.3 \%$ and nine to twelfth for $39.7 \%$ of them. In the West Bank/ Palestine, the Joint Service Council for Solid Waste Management for Hebron and Bethlehem Governorates -JSC-H\&B [7] reported that the waste pickers were working 8 hours daily at Yatta dumpsite during the period when waste was still disposed there. Asim et al. [42] noted that the waste pickers were working an average of 10 hours per day in Pakistan. Thirarattanasunthon et al. [43] showed that waste pickers were working between 6 and 18 hours per day in Thailand.

\subsection{Health Insurance, Professional Union, and Responsible} Body. $99.0 \%$ of waste pickers reported that their safety is not guarded by any government agency, and $87.0 \%$ of them are not belonging to any professional union. However, $90.4 \%$ of them have health insurance, where $22.3 \%$ is governmental health insurance, $39.1 \%$ health insurance offered by the United Nations Relief and Works Agency for Palestinians in the near east (UNRWA) as most of the residents of the Gaza Strip are refugees, and $35.4 \%$ have both governmental and UNRWA health insurance. Interviews with key Palestinian environmental officials (Joint Service Council for Gaza and North Gaza Governorates, Municipal Development and Lending Fund (MDLF), and the Environmental Quality Authority (EQA)), confirmed that all waste pickers are working informally for themselves with no responsible body for their safety. In north Gaza area, the number of waste pickers has been identified and in order to minimize the risks and the number accidents, the responsible personnel issued a particular time frame they were allowed to work in the landfill cells. In addition, the Joint Service Council for Solid Waste Management, North Gaza Branch, decided to restrict the access to the landfill to all (to avoid accidents). Any waste picker enters on his own responsibility having signed an obligation that releases the responsibility of the Joint Service Council for Solid Waste Management toward the waste picker.

3.3. Occupational Health Diseases. The waste pickers were requested to describe any health problem they faced during the last 12 months. More than 50\% of the study sample answered that they were troubled by back pains, breathing issues, skin diseases, sore throat, and cough with high temperature. However, only 30\% complained of intestinal diseases (diarrhea, constipation, and blood with stool), as shown in Figure 1.

Gogoi [44] reported the common diseases affecting scavengers, namely eye irritation (88\%), asthma (76\%), cold and cough (92\%), fatigue (94\%), stomach problems $(20 \%)$, and back pain (96\%). Leton and Nweke [45] studied the health risks of scavengers in 15 dumpsites in Nigeria and found that pending positions and carrying heavy loads of recyclable materials cause backache, pain in legs and arms, and stiffness of joints. Thirarattanasunthon et al. [43] reported that most of the waste pickers suffered from sprains and pains in the lower back (95\%), skin rashes (66\%), 
TABLE 1: Socioeconomic conditions of the waste pickers in the study area.

\begin{tabular}{|c|c|c|c|c|c|c|}
\hline Variable & & & Results & & & \\
\hline & $0-9$ & $10-18$ & $19-30$ & $31-50$ & $\geq 50$ & Total \\
\hline Age & $1.0 \%$ & $24.0 \%$ & $50.2 \%$ & $21.3 \%$ & $3.3 \%$ & $(100 \%)$ \\
\hline Marital status & $\begin{array}{l}\text { Single } \\
47.2 \%\end{array}$ & $\begin{array}{c}\text { Married } \\
52.5 \%\end{array}$ & & & & $\begin{array}{c}\text { Total } \\
100.0 \%\end{array}$ \\
\hline Permanent residence & City & $\begin{array}{l}\text { Refugee } \\
\text { Camp }\end{array}$ & City & & & Total \\
\hline & $83.4 \%$ & $10.6 \%$ & $6.0 \%$ & & & $100.0 \%$ \\
\hline Number of family members & $\leq 4$ & $5-10$ & $11-15$ & $16-20$ & $>20$ & Total \\
\hline Number or ramily members & $20.9 \%$ & $62.5 \%$ & $10.6 \%$ & $1.3 \%$ & $0.7 \%$ & $100.0 \%$ \\
\hline Average monthly income (NIS) from working in & $<500$ & $500-1000$ & $>1000$ & & & Total \\
\hline waste collection & $71.9 \%$ & $27.2 \%$ & $0.7 \%)$ & & & $100.0 \%$ \\
\hline Level of education & Illiterate & Elementary & $\begin{array}{l}\text { Preparatory and } \\
\text { secondary }\end{array}$ & $\begin{array}{l}\text { College or } \\
\text { university }\end{array}$ & & Total \\
\hline & $5.0 \%$ & $30.6 \%$ & $60.5 \%$ & $4.0 \%$ & & $100.0 \%$ \\
\hline Doily working bourc & $\leq 4$ & $5-8$ & $9-12$ & $>12$ & & Total \\
\hline Daily working hours & $3.7 \%$ & $55.3 \%$ & $39.7 \%$ & $1.3 \%$ & & $100.0 \%$ \\
\hline
\end{tabular}

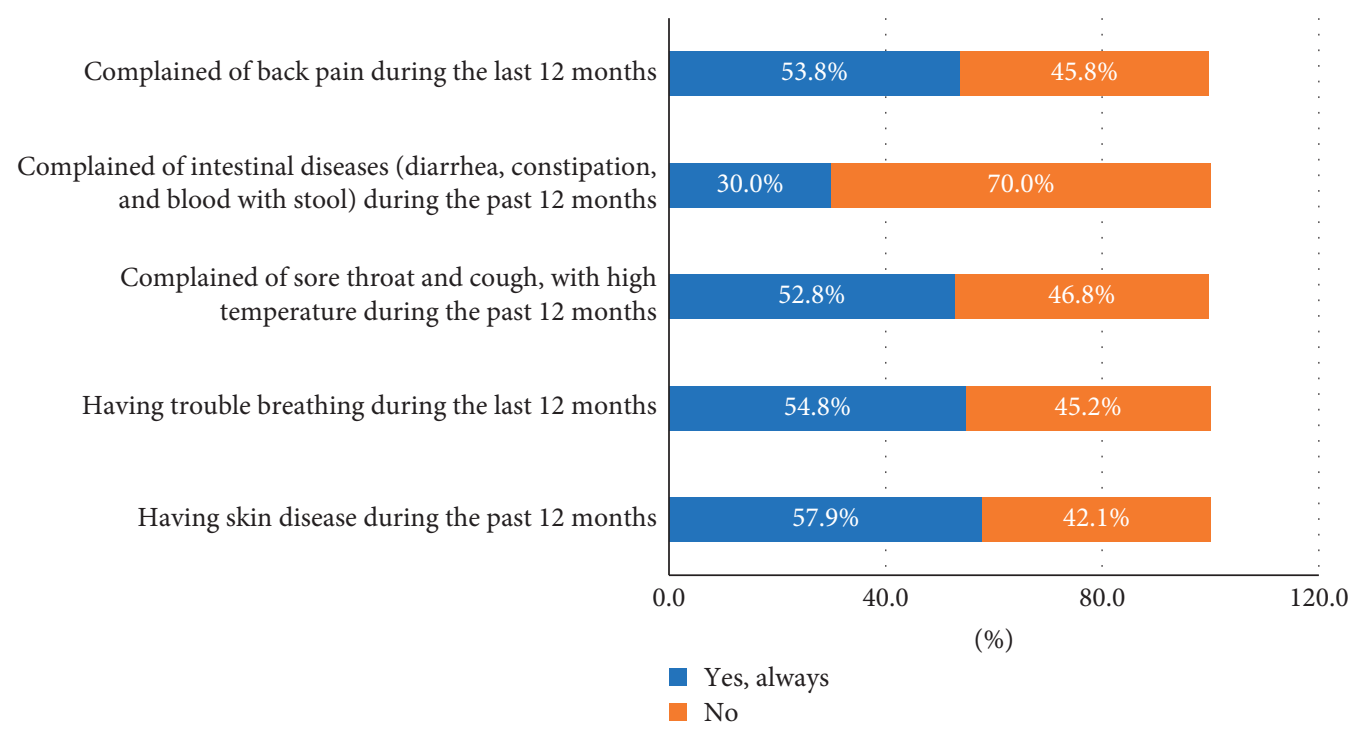

FIgURE 1: Occupational diseases of the waste pickers.

common colds (89\%), fatigue (34\%), headaches (49\%), and shortness of breath (23\%). Diarrhea incidence among informal waste pickers was found to be 10 times greater compared to the general population data [46].

In addition, the surveyed waste pickers were investigated as per their immunization against viral hepatitis and tetanus. The results showed that $61.1 \%$ of them received vaccination against viral hepatitis and $66.4 \%$ received vaccination against tetanus. Vaccination against infectious disease, including tetanus, hepatitis A, and hepatitis B is a successful protective measure that significantly reduces the risks associated with contaminated materials contact [47]. Limited source-separation practices in the municipal waste stream in Palestine means that certain hazardous fractions such as sharp objects, batteries, and medical wastes exist in the waste stream, increasing the vulnerability to risks and the cases of occupational-related diseases. Hunt [48]; highlighted that the official formalization of the waste sorting and recycling activities that can contribute to the protection the workers from health hazards, are at the same time measures for hazardous waste sustainable disposal. To this direction, the risks associated with the collection process can be managed together with the risks of individuals involved in the official collection processes or unofficial one (waste pickers).

3.4. Occupational Safety. The waste pickers were requested to identify safety issues that troubled them during that last 12 months. The results showed that to $58.3 \%$ of them burn injury occurred, and $90.4 \%$ have been exposed to hazardous waste materials such as neglected medicine, bandages, dead animals, paints, batteries, and sharp objects like shaving blades. However, more than three-fourth of them had no incident of sprained foot or joint, a joint dislocation or fracture, and tooth fracture during the last 12 months, while $53.3 \%$ of them have never experienced any muscle tear. The results are shown in Table 2. 
TABLE 2: Occupational safety of the waste pickers.

\begin{tabular}{|c|c|c|c|}
\hline \multirow[b]{2}{*}{ Variable } & \multicolumn{3}{|c|}{ Answer } \\
\hline & $\begin{array}{l}\text { Yes, } \\
\text { always }\end{array}$ & No & Total \\
\hline Having sprained foot during the last 12 months & $61(20.3 \%)$ & $\begin{array}{c}238 \\
(79.3 \%)\end{array}$ & $\begin{array}{c}300 \\
(100 \%)\end{array}$ \\
\hline Having a sprain in the joint during the last 12 months & $47(15.6 \%)$ & $\begin{array}{c}254 \\
(84.4 \%)\end{array}$ & $\begin{array}{c}301 \\
(100 \%)\end{array}$ \\
\hline Having joint dislocation during the last 12 months & $37(12.3 \%)$ & $\begin{array}{c}263 \\
(87.7 \%)\end{array}$ & $\begin{array}{c}300 \\
(100 \%)\end{array}$ \\
\hline Having muscle tear during the last 12 months & $\begin{array}{c}140 \\
(46.7 \%)\end{array}$ & $\begin{array}{c}160 \\
(53.3 \%)\end{array}$ & $\begin{array}{c}300 \\
(100 \%)\end{array}$ \\
\hline Having tooth fracture in the last 12 months & $53(17.6 \%)$ & $\begin{array}{c}248 \\
(82.4 \%)\end{array}$ & $\begin{array}{c}301 \\
(100 \%)\end{array}$ \\
\hline Having scratches/injuries during the last 12 months & $\begin{array}{c}293 \\
(97.7 \%)\end{array}$ & $7(2.3 \%)$ & $\begin{array}{c}300 \\
(100 \%)\end{array}$ \\
\hline Having fracture during the last 12 months & $60(20.1 \%)$ & $\begin{array}{c}239 \\
(79.9 \%)\end{array}$ & $\begin{array}{c}299 \\
(100 \%)\end{array}$ \\
\hline Having burns during the last 12 months & $\begin{array}{c}175 \\
(58.3 \%)\end{array}$ & $\begin{array}{c}125 \\
(41.7 \%)\end{array}$ & $\begin{array}{c}300 \\
(100 \%)\end{array}$ \\
\hline $\begin{array}{l}\text { Exposure to hazards (such as neglected medicines, bandages, dead animals, paints and batteries, and } \\
\text { sharp objects such as shaving blades, glass, or metal parts) during the last } 12 \text { months }\end{array}$ & $\begin{array}{c}272 \\
(90.4 \%)\end{array}$ & $29(9.6 \%)$ & $\begin{array}{c}301 \\
(100 \%)\end{array}$ \\
\hline
\end{tabular}

Parizeau [49] reported exposure of the waste pickers to traffic accidents, broken bones, cuts from glass and sharp metals found in the trash, tiredness and fatigue, burns, aches and pains, and breathing problems. Nguyen et al. [32] also reported that scavengers suffer from pains in the back, headaches, coughs, sore muscles, stomach pains, and rashes, and nearly all respondents of his study suffered from cuts in hands, limbs, and feet. In a comparative study conducted by da Silva et al. [50] between informal waste pickers group and controlled one of similar socioeconomic conditions found that the incident of back pain was similar in both groups pointing the finger to hard work without proper equipment.

3.5. Use of Safety Tools and Hygiene Practices. Scavengers are facing risks similar to the workers in the waste sector, yet in a severe level beyond the expected common diseases such as wounds, cuts in different parts of the body, toxic animal bites, burns and inhalation difficulties due to exposure to chemicals and toxic gases, traffic accidents and falls, and musculoskeletal problems, which are all part of a waste pickers' daily burden [51]. The use of safety tools, personal protective equipment (PPE) and good hygiene practices can, to a large extent, reduce vulnerability to occupational risks. The International Labor organization (ILO) recommendations measures to improve safety of waste pickers which include the use of gloves, safety shoes, tools for waste sorting, and vaccination against tetanus [52]. Limited awareness on potentially risky materials handling together with the limited use of protective equipment makes even household waste hazardous and poses health risks to handlers [47]. The research results showed that more than two-thirds of the waste pickers only sometimes make use of the protective equipment by sharing it; uniforms, masks, hard-covered shoes, and protective gloves, during working hours. It is rather alarming that protective equipment is shared among them, since it is a serious reason for the enhancement of diseases transmission among scavengers. However, $72.1 \%$ of them are always washing their clothes at home, $89.2 \%$ are always bathing after finishing their work, $46.4 \%$ are always using disinfectant in washing work clothes, and only $30.8 \%$ are always washing their hands using disinfectants. The results are shown in Figure 2.

Those are considered as good practices that secure the scavengers' population health level and enhance protection. Nyathi et al. [53] found that only $27.4 \%$ of women scavengers did not use self-protection attire and $69.2 \%$ of men scavenger never used self-protection attire in South Africa. He also found that washing and cleaning of the body is immediately performed by female scavengers after the day's work in the temporary shacks using soap, while men do not clean themselves at work place but do so once they return back home.

In addition, access to clean water and sanitation services, as well as availability of hygienic-appropriate places for meals is another yet important issue that enhances occupational health protection level. The vast majority of the waste pickers reported that clean drinking water is not available at the workplace (86.9\%), neither toilets (96.3\%), nor an appropriate meal place at worksite, as shown in Figure 3. Additionally, the aforementioned basic needs are not covered neither at their homes, undercutting the overall hygienic quality of the population.

3.6. Health and Safety Training. Occupational health and safety training in the field is essential, and it is ascertained that it contributes to the reduction of work accidents and occupational diseases. Nearly no respondents receive any training related to the nature of the work they are carrying out (99.7\%). However, the International Labor organization (ILO) has suggested the implementation of health and safety 


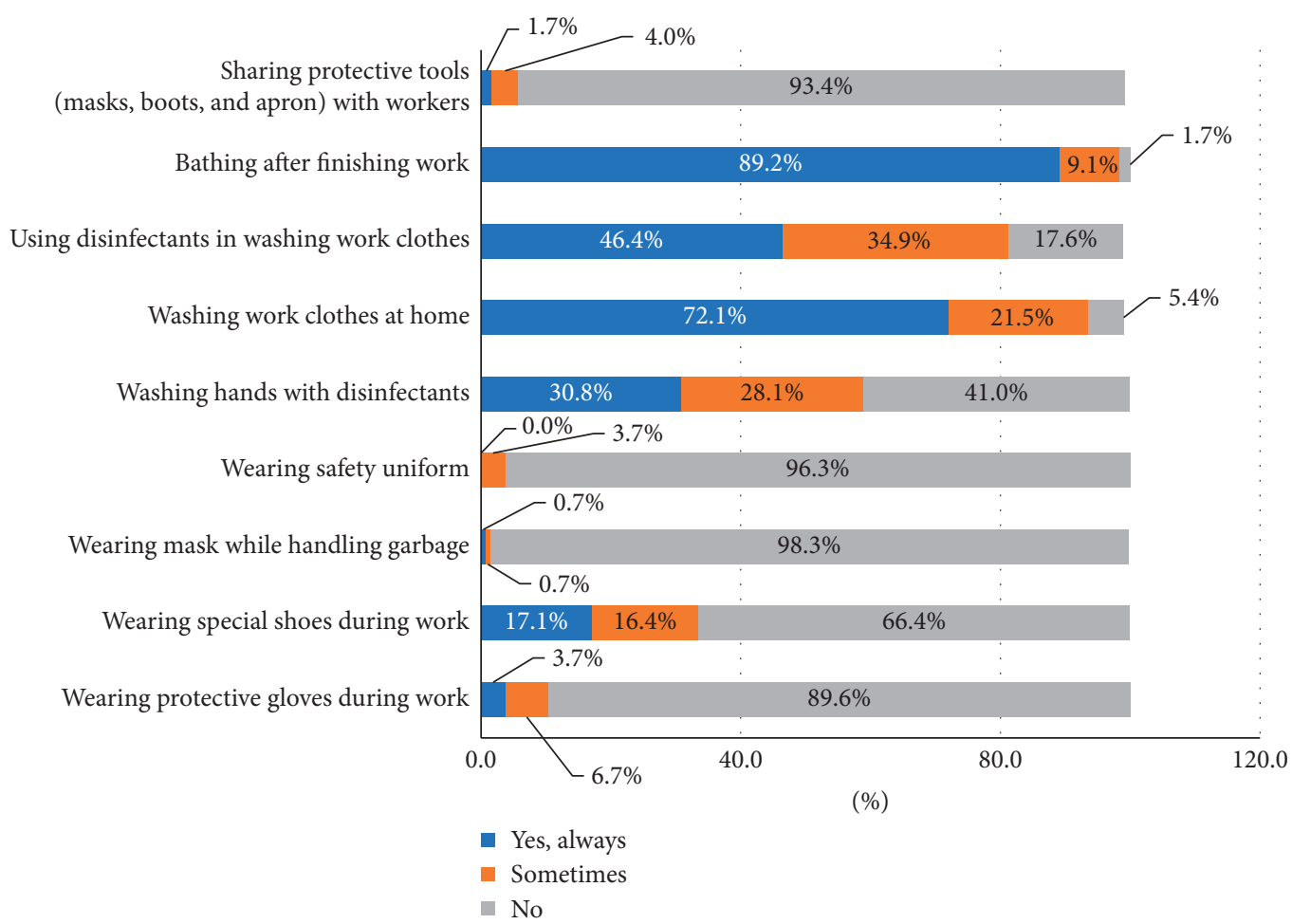

FIGURE 2: Use of safety tools and hygiene practices of the waste pickers.

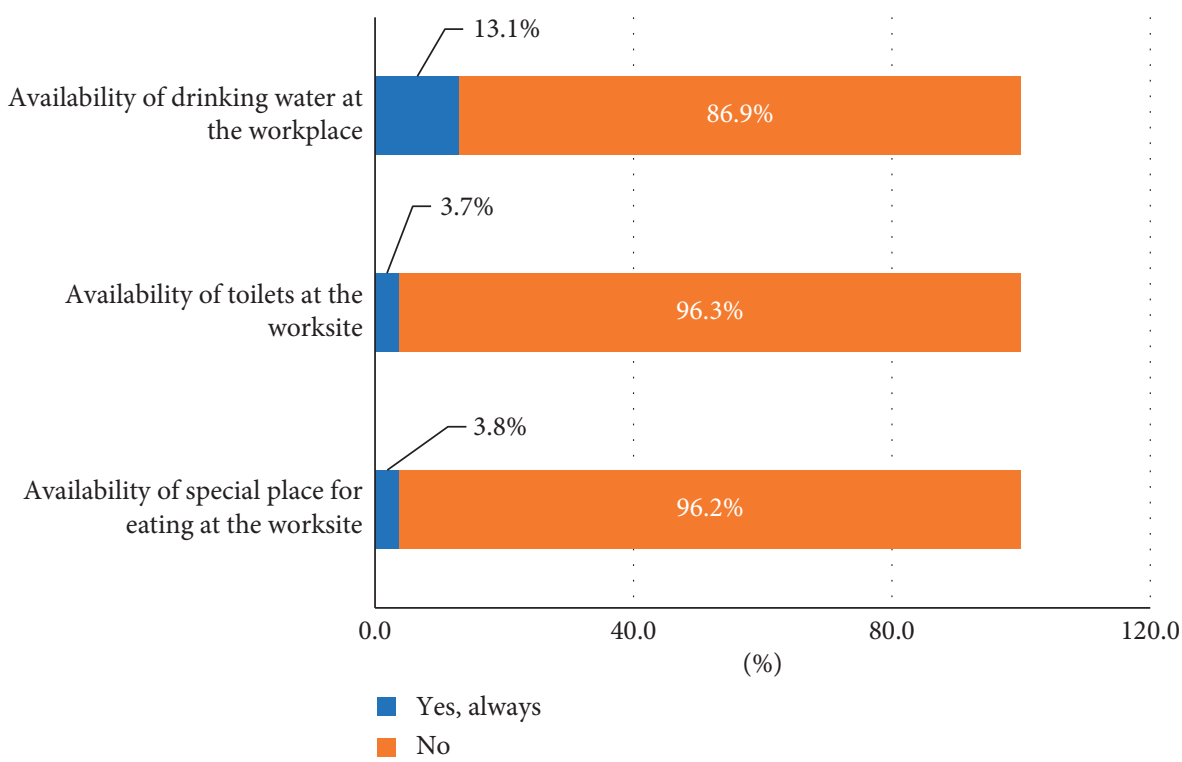

Figure 3: Access to water and sanitation services at the worksite.

training seminars, regular health check-ups, and monitoring of waste pickers in order to safeguard them [52]. Baker et al. [54] conducted a study on the empowerment of informal waste pickers and their active participation to the official municipal solid waste management sector; he found out that waste pickers are highly capable, after a limited training period, to acquire entrepreneurial skills and highly contribute to sustainable solid waste management. The regulation of their work undoubtedly leads to local circular economy and life status enhancement together with the risks exposure reduction.

\section{Conclusions and Recommendations}

Given that the information on waste pickers' livelihood is limited in Palestine, in the Gaza Strip in particular, and this study aims to identify their current occupational health and safety status. Data collection via structured questionnaires 
and direct interviews by 301 waste pickers were backed up with comprehensive information provided by the communication with local key environmental experts.

The results showed that all of the waste pickers in the Gaza Strip are self-employed and are not belonging to any official company or agency. The vast majority of them have health insurance policy issued even by the government or by the UNRWA.

Occupational health and safety level of the waste pickers are limited since during the last 12 months; more than 50\% of the waste pickers suffered from occupational-related diseases, (30\%) from intestinal diseases. On that note, $65 \%$ have burns; the majority has been exposed to hazardous materials. Nevertheless, more than $75 \%$ have not experienced any physical incident (sprained foot, sprained joint, dislocation, fracture, and tooth fracture) during the last 12 months and around $65 \%$ of them have been vaccinated against hepatitis and tetanus.

Overall, more than two-thirds of the waste pickers are using protective equipment (even on a shared basis) and are washing their clothes, but less than half of them use disinfectants regularly. Most importantly, the majority of waste pickers have no access to potable water, sanitation units, and hygienically appropriate place for having meals neither at workplace not at home, which is rather alarming for their health status level. Almost none of the waste pickers have received any occupational health and safety training.

It has been studied and reported that waste pickers' activity may enhance local waste management sector and lead to landfilled solid waste reduction. Solid waste management officials are encouraged to invest in occupational training of the scavengers' population to enhance their skills and provide them with the opportunity to enhance their living status in the meantime by minimizing the waste-borne hazards and vulnerabilities $[55,56]$. That way, in the process of waste separation improvement, waste pickers will simultaneously improve the current occupational health and safety level and gain access to potable water and sanitation. Their formalization attempt may be implemented in collaboration with associations or local companies where safeguarding polices are applicable. Public/private partnership between local authorities and waste pickers associations can eliminate informal recyclables collection and reduce, largely, vulnerability of the waste pickers to risks.

\section{Data Availability}

The data used to support the findings of this study are available from the corresponding author upon request.

\section{Conflicts of Interest}

The authors declare that there are no conflicts of interest regarding the publication of this paper.

\section{Acknowledgments}

The authors are thankful and acknowledge the financial support by the research committee and academic affairs at
Birzeit University, Palestine. They also thank the key Palestinian officials in the Gaza Strip for the insight into scavengers activity provided during the personal interviews conduction in the frame of the research (2019): Abu Al-Qunboz, A. (executive manager of the Joint Service Council for Solid Waste Management for Gaza and North Gaza governorates); Al-Bursh, W. (manager of the Joint Service Council for Solid Waste Management, North Gaza branch); and Mater, S. (Municipal Development and Lending Fund (MDLF)).

\section{References}

[1] B. Steuer, R. Ramusch, and S. P. Salhofer, "Can Beijing's informal waste recycling sector survive amidst worsening circumstances?" Resources, Conservation and Recycling, vol. 128, pp. 59-68, 2018.

[2] P. Kashyap and C. Visvanathan, "Formalization of informal recycling in low-income countries," in Municipal Solid Waste Management in Asia and the Pacific Islands, pp. 41-60, Springer, Singapore, 2014.

[3] Independent, Gaza's Economy Collapsing Due to Israeli Blockade and Massive Funding Cuts, World Bank warns, Independent, London, UK, 2018, https://www.independent.co.uk/news/world/ middle-east/gaza-economy-palestinian-world-bank-israel-westbank-a8554466.html.

[4] M. Vaccari, V. D. Bella, F. Vitali, and C. Collivignarelli, "From mixed to separate collection of solid waste: benefits for the town of Zavidovići (Bosnia and Herzegovina)," Waste Management, vol. 33, no. 2, pp. 277-286, 2013.

[5] S. Sasaki and T. Araki, "Employer-employee and buyer-seller relationships among waste pickers at final disposal site in informal recycling: the case of Bantar Gebang in Indonesia," Habitat International, vol. 40, pp. 51-57, 2013.

[6] Wadi Al-Shaer Joint Service Council for Solid Waste Management-WS-SWM, Environmental Management Project-TF 053262, Resettlement Action Plan for the Anabta Dumpsite Waste Pickers, 2009.

[7] The Joint Service Council for Solid Waste Management for Hebron and Bethlehem Governorates (JSC-H\&B), 2015, http://hjsc-swm.com/articles/hjsc-news/waste-pickers-areutilizing-biogas-from-yatta-dumpsite-for-daily-needs/.

[8] Eco Con Serv Environmental Solutions and Universal Group, Gaza Solid Waste Management Project, Abbreviated Resettlement Action Plan for El-Fukhary Landfill, Eco Con Serv Environmental Solutions and Universal Group, Gaza, Israel, 2013.

[9] M. El-Hawi, "Recycling of the municipal solid waste in the Gaza Strip," in Proceedings of the 28th WEDC Conference Sustainable Sanitation and Water Services, Kolkata, India, November 2002.

[10] D. C. Wilson, C. Velis, and C. Cheeseman, "Role of informal sector recycling in waste management in developing countries," Habitat International, vol. 30, no. 4, pp. 797-808, 2006.

[11] J. Gutberlet and A. M. Baeder, "Informal recycling and occupational health in Santo André, Brazil," International Journal of Environmental Health Research, vol. 18, no. 1, pp. 1-15, 2008.

[12] J. Gutberlet, "Briefing: social facets of solid waste: insights from the global south," Proceedings of the Institution of Civil Engineers-Waste and Resource Management, vol. 166, no. 3, pp. 110-113, 2013.

[13] S. M. N. Uddin and J. Gutberlet, "Livelihoods and health status of informal recyclers in Mongolia," Resources, Conservation and Recycling, vol. 134, pp. 1-9, 2018. 
[14] E. Gunsilius, "Emerging trends in informal sector recycling in developing and transition countries," Waste Management, vol. 33, pp. 2509-2519, 2012.

[15] Y. Hayami, A. K. Dikshit, and S. N. Mishra, "Waste Pickers and Collectors in Delhi: Poverty and environment in an urban informal sector," Journal of Development Studies, vol. 42, pp. 41-69, 2006.

[16] R. D. P. Moreno-sánchez and J. H. Maldonado, "Surviving from garbage: the role of informal waste-pickers in a dynamic model of solid-waste management in developing countries," Environment and Development Economics, vol. 11, no. 3, pp. 371-391, 2006.

[17] A. Ruiz-Restrepo and S. Barnes, "WIEGO report on the policy environment of informal urban waste pickers and artisanal mine workers in Colombia," http://wiego.org/sites/wiego.org/ files/publications/files/WIEGO report, WIEGO, Cambridge, MA, USA, 2010, http://wiego.org/sites/wiego.org/files/ publications/files/WIEGO report.

[18] D. Wilson, A. Whiteman, and A. Tormin, Strategic Planning Guide for Municipal Solid Waste Management, World Bank, Washington, DC, USA, 2001.

[19] K. Parizeau, "Urban political ecologies of informal recyclers' health in Buenos Aires, Argentina," Health \& Place, vol. 33, pp. 67-74, 2015.

[20] C. Auer, "Health status of children living in as quatter area of Manila, Philippines, with particular emphasis on intestinal parasitoses," Southeast Asian Journal of Tropical Medical Public Health, vol. 21, no. 2, pp. 289-300, 1990.

[21] M. C. Da Silva, A.., G. Fassa, C.., E. Siqueira, and y., D. Kriebel, "World at work: Brazilian ragpickers," Occupational and Environmental Medicine, vol. 62, no. 10, pp. 736-740, 2005.

[22] S. Gunn and Z. Ostos, "Dilemmas in tackling child labor: the case of scavenger children in the Philippines," International Labor Review, vol. 131, no. 6, pp. 629-646, 1992.

[23] C. Hunt, "A review of the health hazards associated with the occupation of waste picking for children," International Journal of Adolescent Medicine and Health, vol. 13, no. 3, pp. 177-189, 2001.

[24] N. Kungskulniti, "Public health aspects of a solid waste scavenger community in Thailand," Waste Management \& Research, vol. 8, no. 2, pp. 167-171, 1990.

[25] M. R. Ray, G. Mukherjee, S. Roychowdhury, and T. Lahiri, "Respiratory and general health impairments of ragpickers in India: a study in Delhi," International Archives of Occupational and Environmental Health, vol. 77, no. 8, pp. 595-598, 2004.

[26] M. Van Eerd, "The occupational health aspects of waste collection and recycling: an inventory study in India," UWEP, Gouda, Netherlands, 1997, http://www.waste.nlUWEP Working Document 4.

[27] E. Binion and J. Gutberlet, "The effects of handling solid waste on the wellbeing of informal and organized recyclers: a review of the literature," International Journal of Occupational and Environmental Health, vol. 18, no. 1, pp. 43-52, 2012.

[28] G. Jutta and A. M. Baeder, "Informal recycling and occupational health in Santo André, Brazil," International Journal of Environmental Health Research, vol. 18, no. 1, pp. 1-15, 1997.

[29] S. Cointreau, Occupational and Environmental Health Issues of Solid Waste Management. Special Emphasis on Middle- and Lower-Income Countries, Urban Sector Board, The World Bank Group, Washington, DC, USA, 2006.

[30] L. Rushton, "Health hazards and waste management," British Medical Bulletin, vol. 68, no. 1, pp. 183-197, 2003.
[31] P. P. F. M. Kuijer, "World at work: refuse collectors," Occupational and Environmental Medicine, vol. 61, no. 3, pp. 282-286, 2006.

[32] H. Nguyen, C. Chalin, T. Lam, and V. Maclaren, Health \& Social Needs of Waste Pickers in Vietnam, University of Toronto, Toronto, Canada, 2003.

[33] United Nations Environment Programme (UNEP), Solid waste management, Vol. 1, International Environmental Technology Centre (IETC), Osaka, Japan, 2005.

[34] I. A. Al-Khatib, Solid Waste Management: Impact on the Safety of Waste Handlers in Developing Countries, LAP LAMBERT Academic Publishing, Saarbrücken, Germany, 2010.

[35] Municipal Development and Lending Fund-MDLF, "Environmental and social impact assessment report for al-menya landfill site," Municipal Development and Lending Fund-MDLF, Ramallah, Palestine, Southern West Bank Solid Waste Management Project, 2009.

[36] R. Al-Rujoub, I. A. Al-Khatib, N. Al-Shami, and J. I. Salahat, "Occupational safety and health practices among farmers in Wadi Al Fara' Area, Palestine," Palestinian Journal of Technology \& Applied Sciences, vol. 2, pp. 49-60, 2019.

[37] C... J. Schenck, D. Blaauw, and K. Viljoen, Unrecognised Waste Management Experts: Challenges and Opportunities for Small Business Development and Decent Job Creation in the Waste Sector in the Free State; Research Report for a Study Completed for the South Africa SME Observatory Tourism and Environmental Aairs of the Free State Province (DETEA) and the International Labour Organization, hosted by the Department of Economic Development ILO), Geneva, Switzerland, 2012.

[38] P. S. Figueiredo, J. Dantas, P. Figueiredo et al., "The socioeconomic conditions of waste pickers in Bahia, and an evaluation of a workforce restructuring a multiple case study," Revista de Gestão Social e Ambiental-RGSA, vol. 11, no. 1, pp. 2-20, 2017.

[39] C. J. Schenck, P. F. Blaauw, J. M. M. Viljoen, and E. C. Swart, "Exploring the potential health risks faced by waste pickers on landfills in South Africa: a socio-ecological perspective," International Journal of Environmental Resources and Public Health, vol. 16, no. 11, p. 2059, 2019.

[40] M. S. Maria and M. Samson, Informal Economy Monitoring Study Sector Report: Waste Pickers, Women in Informal Employment: Globalizing and Organizing-WIEGO, London, UK, 2016.

[41] The United Nations Inter-Agency Task Force on Social and Solidarity Economy-UNTFSSE, "Waste picker social economy organizations addressing the Sustainable Development Goals," in Proceedings of the UNTFSSE International Conference, Geneva, Switzerland, 2019.

[42] M. Asim, S. A. Batool, and M. N. Chaudhry, "Scavengers and their role in the recycling of waste in southwestern Lahore," Resources, Conservation and Recycling, vol. 58, pp. 152-162, 2012.

[43] P. Thirarattanasunthon, W. Siriwong, M. G. Robson, and M. Borjan, "Health risk reduction behaviors model for scavengers exposed to solid waste in municipal dump sites in Nakhon Ratchasima province, Thailand," Risk Management and Healthcare Policy, vol. 5, pp. 97-104, 2012.

[44] L. Gogoi, "Occupational health hazard of waste pickers in the vicinity of dumping ground: a case study of west boragaon dumpsite, Guwahati, India," International Journal of Interdisciplinary Research in Science Society and Culture (IJIRSSC), vol. 1, no. 1, pp. 72-83, 2015. 
[45] T. G. Leton and V. N. Nweke, "Health risk of domestic solid waste scavenging," Journal of Environmental and Behavior, vol. 1, pp. 35-38, 2003.

[46] S. Cointreau, Occupational and Environmental Health Issues of Solid Waste Management: Special Emphasis on Developing Countries, World Health Organization (WHO), Geneva, Switzerland, 2006.

[47] J. Gutberlet and S. M. N. Uddin, "Household waste and health risks affecting waste pickers and the environment in low- and middle-income countries," International Journal of Occupational and Environmental Health, vol. 23, no. 4, pp. 299-310, 2017.

[48] C. Hunt, "Child waste pickers in India: the occupation and its health risks," Environment and Urbanization, vol. 8, no. 2, pp. 111-118, 1996.

[49] K. Parizeau, "La salud de loscartoneros de Buenos Aires," in Recicloscopio II: Miradassobrerecuperadoresurbanos de Residuos de Ame'rica Latina, Sua'rez and Schamber, Eds., Prometeo-UNL, Buenos Aires, Argentina, 2011.

[50] M. C. da Silva, A. G. Fassa, and D. Kriebel, "Musculoskeletal pain in ragpickers in a southern city in Brazil," American Journal of Industrial Medicine, vol. 49, no. 5, pp. 327-336, 2006.

[51] U. Samarth, The Occupational Health of Waste Pickers in Pune: KKPKP and SWaCH Members Push for Health Rights, Women of Informal Employment Globalizing and Organizing-WIEGO, London, UK, 2014.

[52] International Labor Organization-ILO, Addressing the Exploitation of Children in Scavenging (Waste Picking): A Thematic Evaluation of Action on Child Labor. A Thematic Evaluation, International Labor Organization, Geneva, Switzerland, 2004.

[53] S. Nyathi, J. O. Olowoyo, and A. Oludare, "Perception of scavengers and occupational health hazards associated with scavenging from a waste dumpsite in pretoria, South Africa," Journal of Environmental and Public Health, vol. 2018, Article ID 9458156, 7 pages, 2018.

[54] M. Baker, S. Memela, and N. Rampete, "Empowerment of Waste Pickers in the City of Johannesburg, creating an enabling environment for the informal waste sector to participate in municipal waste service delivery," in Proceedings of the 23rd WasteCon Conference, Emperors Palace, Johannesburg, South Africa, 2016.

[55] J. M. L. Kironde and M. Yhdego, "The governance of waste management in urban Tanzania: towards a community based approach," Resources, Conservation and Recycling, vol. 21, no. 4, pp. 213-226, 1997.

[56] J. C. V. D. León and J. J. Bogardi, "Focusing on the environment and human security nexus," in Geophysical Hazards: Minimizing Risk, Maximizing Awareness, T. Beer, Ed., Springer, Berlin, Germany, 2010. 